\title{
Effect of Composting Of Different Organic Wastes with Earthworm Species on C: N Ratio.
}

\author{
R. S. Chaudhari ${ }^{1}$, W. P. Badole ${ }^{2}$, Smita R.Chaudhari ${ }^{3}$ \\ 1 Subject Matter Specialist, Krishi Vigyan Kendra, Jalna. \\ 2 Asst. Prof College of Agriculture Nagpur. \\ 3 Asst. Prof; College of Agriculture, Kharpudi
}

\begin{abstract}
A vermicomposting study was conducted with different organic waste like wheat straw, cotton stubble waste and leaf litter by using five species of earthworms i.e. Eisenia foetida, Eudrilus eugeniae, Perionyx excavatus, Lampito mauritii and one local. Lowest $C: N$ ratio was recorded in cotton waste inoculated with Eisenia foetida over all other combinations except cotton waste inoculated with Lampito mauritii and leaf litter inoculated with Eisenia foetida and Lampito mauritii.

Key words: Earthworm, C:N ratio.
\end{abstract}

\section{Introduction}

A large amount organic materials from various sources are available in the country and which can be good supplement not only for plant nutrient but also as a soil amendment. As per survey of India approximately 388.75 million tonnes of agricultural waste, 2073.8 million tonnes of poultry and animal waste, 150 million tonnes of community waste are generated (Adhikari et al., 1997). In all the above waste 7.589, 2.515, 7.457 million tonnes of N, P and K respectively are being wasted. The unutilised part of nutrient of these wastes should be recorded and reduced by compost technology. Therefore it is huge scope to produce energy by organic matter recycling and increase soil productivity.

Organic wastes of biodegradable nature are an essential input to sustainable agriculture. The farm produced crop residue and other organic waste are valuable agricultural input as source of soil organic matter and essential nutrient elements required for crop growth. There by minimize the environmental pollution (Poincelot, 1974). Normally six to seven months are required to decompose organic material. But the decomposition of such organic waste completed 45 days due to addition of earthworm culture (Jambhekar, 1992). Out of all earthworm species Eisenia feetida, Eudrilus eugeniae, Perionyx excavatus. Dendrobance venata are organic waste decomposer (Kale and Bano, 1987).

The present study carried out to asses change in C:N ratio during decomposition by different earthworm species.

\section{Materials And Methods}

The present investigation carried out at College of Agriculture, Nagpur by selecting organic residue i.e. Wheat straw (Ws), Cotton stubble waste $(\mathrm{Cw})$ and Leaf litter (Ll) were decomposed with the help of Eisenia foetida (Ef), Eudrilus eugeniae (Ee), Perionyx excavatus (Px), Lampito mauritii (Lm) and Local species of Nagpur in FRBD design. Before preparation of vermibed, the organic waste was covered separately with cow dung sprinkle water for partial decomposition upto 25 days. Then $22.5 \mathrm{~kg}$. of organic waste for each bed of size $1 \mathrm{~m} \times 1 \mathrm{~m} \times 0.3 \mathrm{~m}$ was taken and spread $2.5 \mathrm{~kg}$ cow dung and $375 \mathrm{gm}$ gypsum. Then 75 number of earthworm of each species added as per following treatments: 1) $\mathrm{T}_{1}-\mathrm{Ws}+\mathrm{Ef}$, 2) $\mathrm{T}_{2}-\mathrm{Ws}+\mathrm{Ee}$, 3) $\mathrm{T}_{3}-\mathrm{Ws}+\mathrm{Px}$, 4) $\mathrm{T}_{4}-\mathrm{Ws}$ $+\mathrm{Lm}$, 5) $\left.\left.\left.\mathrm{T}_{5}-\mathrm{Ws}+\mathrm{L}, 6\right) \mathrm{T}_{6}-\mathrm{Cw}+\mathrm{Ef}, 7\right) \mathrm{T}_{7}-\mathrm{Cw}+\mathrm{Ee}, 8\right) \mathrm{T}_{8}+\mathrm{Cw}+\mathrm{Px}$, 9) $\mathrm{T}_{9}-\mathrm{Cw}+\mathrm{Lm}$, 10) $\mathrm{T}_{10}-\mathrm{Cw}+\mathrm{L}$, 11) $\mathrm{T}_{11}-\mathrm{Ll}+\mathrm{Ef}$ 12) $\mathrm{T}_{12}-\mathrm{Ll}+\mathrm{Ee}$, 13) $\mathrm{T}_{13}-\mathrm{Ll}+\mathrm{Px}$, 14) $\left.\mathrm{T}_{14}-\mathrm{Ll}+\mathrm{Lm}, 15\right) \mathrm{T}_{15}-\mathrm{Ll}+\mathrm{L}$. The sample was taken periodically from $50^{\text {th }}$ day to $90^{\text {th }}$ day at 10 days of interval. The over dried degraded substance were analysed from organic carbon and total nitrogen by ignition method (Jackson, 1973) and Kjeldahl method (Piper, 1966) respectively.

\section{ORGANIC CARBON}

\section{Result And Discussion}

The results of periodic observation of organic carbon were statistically significant. Amongst the earthworm species lower organic carbon was recorded throughout study period from 50 DAI (31.54\%) to 90 DAI (17.73\%) by Eisenia foetida over local and Perionyx excavatus. However the results of Eisenia foetida was at par throughout the study period with Eudrilus eugeniae and Lampito mauritii. The reduction in the rate of lowering of organic carbon content was very slower after 80 DAI. In vermicomposting of organic waste, the reduction of organic carbon during initial period was at very faster rate in wheat straw i.e. at 60 days recorded 
significantly lower organic carbon content $(30.13 \%)$ and in later period of 70 to $80(19.87 \%)$ day the decomposition rate of cotton stubble was faster and recorded lowest organic carbon content at $90^{\text {th }}$ day $(19.50 \%)$ (Table 1). The result shows efficiency of earthworm which might be related with the softness of organic residue because at initial stage, the wheat straw was softer and with increase in period, cotton waste become softer and their after leaf litter. It is discussed at that probably volatile potentiaators of modifier are responsible for feeding behavior of worms (Kale and Krishnamoorthy, 1981).

\section{IV. total nitrogen}

The content of nitrogen during decomposition period were slightly improved and recorded significantly maximum by Eisenia foetida, Eudrilus eugeniae and Lampito maurtii over Perionyx excavatus and local species of earthworm. The significantly maximum content of nitrogen was recorded by Eisenia foetida (1.556\%) followed by Eudrilus engeniae (1.549\%) and Lampito mauritii (1.531\%) over Perionyx excavatus $(1.390 \%)$ and local species $(1.367 \%)$ at 90 days. Similar trend of increase in nitrogen content due to addition of earthworm was recorded by Arumugam et al. (2004) In vermicompost of different organic waste recorded significant result on content of nitrogen (Table 2). Significantly maximum content of $\mathrm{N}$ was recorded throughout decomposition period in leaf litter $(1.305 \%-1.569 \%)$ followed by cotton waste $(1.266-1.508 \%)$ and wheat straw $(1.076-1.359 \%)$. The maximum content of total $\mathrm{N}$ was associated with maximum content of nitrogen in organic waste residue at initial stage.

\section{C:N Ratio}

The result showed that the decomposition rate was very faster during initial period and recorded significantly lowest C:N ratio by Lampito mauritii (20.88:1) at 60 days over Perionyx excavatus (20.89:1) and Local (28.03:1). However the result were at par with Eiseniae foetida (20.89:1) and Eudrilus engeniae $(21.17: 1)$ at $60^{\text {th }}$ day. The results showed that the maturity of vermicompost of different organic waste attend within 60 days by Lampito mauritii, Eisenia foetida and Eudrilus eugeniae. However Perionyx excavatus takes 70 days $(20.49: 1)$ and local species takes 80 days $(18.01: 1)$. In latter period at $70^{\text {th }}$ day the lowest $\mathrm{C}: \mathrm{N}$ ratio $(15.38: 1)$ to $90^{\text {th }}$ day (11.58:1) was recorded by Eisenia foetida which was at par with Lampito mauritii and significantly superior over other species of earthworm Eudrilus eugeniae, Perionyx excavatus and local species. The stabilization in C:N ratio was recorded after 80 days because much reduction was not recorded at $90^{\text {th }}$ day (Table 3). Similar observation was found in reduction of $\mathrm{C}: \mathrm{N}$ ratio due to decomposition of organic waste through earthworm (Daudt et al., 2004).

The result of C:N ratio due to different organic source are also significantly enfluenced throughout decomposition period. The complete decomposition of leaf litter (17.53:1) and wheat straw (19.89:1) was recorded at $70^{\text {th }}$ day. Further decomposition was significantly faster in cotton stubble (13.01:1) over wheat straw (15.62:1) and at par with leaf litter (13.14:1) The decomposition of wheat is relatively faster at beginning but slower down after four weeks by the end of 21 weeks (Mishra et al., 1982).

\section{Conclusions}

Considering the $\mathrm{C}: \mathrm{N}$ ratio the complete decomposition of cotton stubble waste was recorded in 60 days by Lampito mauritii, Eisenia foetida and Eudrilus engeniae. The Eudrilus engeniae completely decomposed the leaf litter in 60 days and wheat straw in 70 days. Perionyx excavatus takes 70 days for complete decomposition of cotton waste and leaf litter waste and for wheat straw, it required 80 days. However, local earthworm completely decomposed the wheat straw, cotton stubble waste and leaf litter in 80 days. The stabilization in C : N ratio was recorded after 70 days in Eisenia foetida, Eudrilus eugeniae and Lampito mauritii.

\section{References}

[1]. Adhikari, T. M., Manna, C. and Biswas, A. K. Organic matter improves soil health an overview. Indian Farming (November), 1997, 11-14.

[2]. Arumugam, G. K., Ganeshan, S., Kandesam, R. , Balasubramani, R. and Burusa, P. R., Municipal solid waste management through anaecic earthworm Lampito mauritii and their role in mircobial modification, 2004, http://www.eco.web.com.

[3]. Daudt, C. E., Dutra, L. C., Penna, N. G. and Fogaca, A. de O. Composting and vermicomposting in grape pomace. Vermicompostagem e compostagem do bagaco de uvas. Higiene Alimenator, 2004, 18 (118): 31 - 37.

[4]. Jackson, M. L. Soil chemical analysis. Prentice Hall of India Private Limited, New Delhi. 1973.

[5]. Jambhekar, H. A. Use of earthworm as a potential source to decompose organic waste. Proceeding of the national seminar on organic farming. 1992 , p.p. 52.

[6]. Kale R. D. and Bano, K., Culturing of earthworm Eudrilus eugeniae for cast production. J. Soil Bio. Eco., 1987,7 (2) : 98 - 104.

[7]. Kale R. D. and Krishnamoorthy, R.V. Litter preference in the earthworm Lampito mauritii. Proc. Indian Acod. Sci. (Anim. Sci.), $1981,40(1): 123-128$.

[8]. Mishra, M. M., Kapoor K.K. and Yadav, K.S. Effect of compost enriched with Mussoorie rock phosphate on crop yield. Indian J. Agric. Sci. 1982, 52(10): 675-678.

[9]. Piper, C. S. Soil and plant analysis IV ${ }^{\text {th }}$ Ed University of Acelcide, Adeilade, Australia, 1966, 133-200. 
[10]. Poincelot, R. P. A scientific examination of the principles and practices of composting. Comp. Sci. , 1974, 15(3) : 34

Table 1 : Effect of earthworm and source of organic waste on periodic content of organic carbon.

\begin{tabular}{|c|c|c|c|c|c|}
\hline & 50 DAI & 60 DAI & 70 DAI & 80 DAI & 90 DAI \\
\hline \multicolumn{6}{|c|}{ Earth warm (EW) } \\
\hline E. foetida & 31.54 & 28.20 & 21.58 & 17.96 & 17.73 \\
\hline E.eugeniae & 31.69 & 28.38 & 22.29 & 18.78 & 18.59 \\
\hline P. excavatus & 36.96 & 33.20 & 26.81 & 23.20 & 23.02 \\
\hline L. mauritii & 31.82 & 28.22 & 22.11 & 17.88 & 17.91 \\
\hline Local & 36.25 & 33.20 & 28.78 & 24.15 & 24.04 \\
\hline S.E. $\pm(\mathrm{m})$ & 0.38 & 0.2 & 0.12 & 0.12 & 0.13 \\
\hline C.D. $(P=0.05)$ & 1.11 & 0.57 & 0.35 & 0.35 & 0.39 \\
\hline \multicolumn{6}{|c|}{ Organic waste (OW) } \\
\hline Wheat straw & 33.23 & 30.13 & 24.93 & 21.11 & 20.98 \\
\hline Cotton stubble & 33.95 & 30.29 & 23.60 & 19.67 & 19.50 \\
\hline Leaf litter & 33.78 & 30.76 & 24.42 & 20.40 & 20.29 \\
\hline S.E. $\pm(\mathrm{m})$ & 0.296 & 0.152 & 0.093 & 0.095 & 0.103 \\
\hline C.D. $(P=0.05)$ & 0.86 & 0.44 & 0.27 & 0.27 & 0.30 \\
\hline \multicolumn{6}{|c|}{ Interaction (Ew x OW) } \\
\hline S.E. $\pm(\mathrm{m})$ & 0.66 & 0.34 & 0.2 & 0.21 & 0.23 \\
\hline C.D. $(P=0.05)$ & 1.91 & 0.99 & 0.60 & 0.61 & 0.67 \\
\hline C. V. (\%) & 3.40 & 1.94 & 1.48 & 1.8 & 1.97 \\
\hline
\end{tabular}

Table 2 : Effect of earthworm and source of organic waste on periodic content of total nitrogen.

\begin{tabular}{|c|c|c|c|c|c|}
\hline & 50 DAI & $60 \mathrm{DAI}$ & 70 DAI & 80 DAI & 90 DAI \\
\hline \multicolumn{6}{|c|}{ Earth warm (EW) } \\
\hline E. foetida & 1.258 & 1.358 & 1.419 & 1.530 & 1.556 \\
\hline E. eugeniae & 1.257 & 1.364 & 1.399 & 1.506 & 1.549 \\
\hline P. excavatus & 1.159 & 1.251 & 1.320 & 1.377 & 1.390 \\
\hline L. mauritii & 1.297 & 1.353 & 1.414 & 1.509 & 1.531 \\
\hline Local & 1.107 & 1.248 & 1.279 & 1.313 & 1.367 \\
\hline S.E. $\pm(m)$ & 0.0081 & 0.0089 & 0.013 & 0.017 & 0.0074 \\
\hline C.D. $(\mathrm{P}=0.05)$ & 0.023 & 0.026 & 0.039 & 0.049 & 0.021 \\
\hline \multicolumn{6}{|c|}{ Organic waste $(\mathrm{OW})$} \\
\hline Wheat straw & 1.076 & 1.183 & 1.263 & 1.355 & 1.359 \\
\hline Cotton stubble & 1.266 & 1.371 & 1.405 & 1.456 & 1.508 \\
\hline Leaf litter & 1.305 & 1.390 & 1.431 & 1.530 & 1.569 \\
\hline S.E. $\pm(\mathrm{m})$ & 0.0062 & 0.007 & 0.010 & 0.013 & 0.006 \\
\hline C.D. $(\mathrm{P}=0.05)$ & 0.018 & 0.020 & 0.030 & 0.038 & 0.017 \\
\hline \multicolumn{6}{|c|}{ Interaction (Ew x OW) } \\
\hline S.E. $\pm(m)$ & 0.014 & 0.015 & 0.025 & 0.029 & 0.013 \\
\hline C.D. $(P=0.05)$ & 0.040 & 0.045 & 0.069 & N.S. & 0.037 \\
\hline C.V.(\%) & 1.99 & 2.03 & 2.95 & 3.53 & 1.5 \\
\hline
\end{tabular}

Table 3 : Effect of earthworm and source of organic waste on periodic content of $\mathrm{C}: \mathrm{N}$ ratio.

\begin{tabular}{|c|c|c|c|c|c|}
\hline & 50 DAI & 60 DAI & 70 DAI & 80 DAI & 90 DAI \\
\hline \multicolumn{6}{|c|}{ Earth warm (EW) } \\
\hline E. foetida & 25.02 & 20.89 & 15.38 & 11.89 & 11.58 \\
\hline E. eugeniae & 25.40 & 21.17 & 16.02 & 12.56 & 12.25 \\
\hline P. excavatus & 32.15 & 26.71 & 20.49 & 16.92 & 16.48 \\
\hline L. mauritii & 24.72 & 20.88 & 15.71 & 11.93 & 11.64 \\
\hline Local & 33.83 & 28.03 & 22.52 & 18.01 & 17.66 \\
\hline S.E. $\pm(m)$ & 0.345 & 0.289 & 0.205 & 0.1 & 0.163 \\
\hline C.D. $(P=0.05)$ & 1.00 & 0.84 & 0.59 & 0.29 & 0.47 \\
\hline \multicolumn{6}{|c|}{ Organic waste (OW) } \\
\hline Wheat straw & 31.84 & 25.60 & 19.89 & 15.74 & 15.62 \\
\hline Cotton stubble & 26.96 & 22.44 & 16.65 & 13.44 & 13.00 \\
\hline Leaf litter & 25.87 & 22.58 & 17.53 & 13.55 & 13.14 \\
\hline S.E. $\pm(\mathrm{m})$ & 0.266 & 0.224 & 0.159 & 0.078 & 0.127 \\
\hline C.D. $(\mathrm{P}=0.05)$ & 0.77 & 0.65 & 0.46 & 0.22 & 0.37 \\
\hline \multicolumn{6}{|c|}{ Interaction (Ew x OW) } \\
\hline S.E. $\pm(\mathbf{m})$ & 0.598 & 0.501 & 0.355 & 0.173 & 0.283 \\
\hline C.D. $(P=0.05)$ & 1.73 & 1.45 & 1.03 & 0.50 & 0.82 \\
\hline C. V. (\%) & 3.67 & 3.69 & 3.41 & 2.10 & 3.52 \\
\hline
\end{tabular}

